\title{
Physicians prepare guidelines on use of human genome data
}

London. The World Medical Association (WMA) - which brings together the professional physicians' organizations from 64 countries - has agreed to draw up a set of guidelines covering the medical use of information derived from the sequencing of the human genome.

The WMA's move follows similar proposals already adopted by the International Bar Association, which is in the process of preparing a document covering the legal use of such information.

A draft of the guidelines for doctors was presented last week by the Belgian Medical Association to a council session of the WMA held in Bali, Indonesia. The guidelines would take the form of a statement by the WMA on predictive medicine, and follow an earlier declaration on the Human Genome Project issued by the association in 1992.

Each member organization has agreed to discuss the current draft with its members. The results of these consultations will then be discussed by the WMA next year, with a view to producing an agreed text to act as global guidelines for the medical profession.

"The issues to be covered are becoming more urgent as each month passes," says Nigel Duncan, a spokesman for the WMA.

The statement as proposed by the Belgian doctors includes several tough restrictions. In particular, it says that any genetic diagnosis for a predicted condition "should only be performed when a therapeutic or prophylactic remedy is available, or when an estimate of the risk of transmission can assist parents in making reproductive decisions".

This is likely to be modified by pressure from individual WMA members. The British Medical Association, for example, pointed out in Bali that there are other advantages in predictive screening - such as suggesting possible changes in lifestyle in the face of a potential health threat - even for diseases that are not curable.

Others are expected to object to the harshness of a separate clause that warns that natural selection would be under threat if the various prophylactic measures made possible by knowledge of the human genome bring about the survival - and therefore the reproduction - of individuals presented altered genes.

Nevertheless, widespread support is likely among professional medical bodies for the general thrust of the statement, namely that doctors have a responsibility to ensure that care is taken when using the techniques of predictive medicine, to ensure individual patients are equipped to cope with the implications of the knowledge that these techniques can reveal. David Dickson

\section{Call for partnership projects to join $\mathbf{8 8 0}$ million scheme}

London. The UK government's bid to quell disquiet within the scientific community over its attempts to bring research closer to industry continued last week with the launch of an $£ 80$-million (US\$124-million) scheme to back research projects aimed at creating wealth and improving the quality of life.

The so-called Foresight Challenge, which was first announced in May and whose funding will be shared equally by government and the private sector, is being described as a competition to attract bids in line with the recommendations of the government's Technology Foresight exercise (see Nature 375, 265; 1995). The funding will last three years.

The competition was launched on Monday by Ian Taylor, the junior minister for science and technology. Earlier, at a press briefing, Robert May, the government's chief scientific adviser, invited "imaginative proposals" with an annual cost in the range of $£ 1-2$ million from groups comprising partnerships of industry and academia. Projects falling below this threshold will not be ruled out. But the upper limit of public sector contributions will be $£ 4$ million.

Short outlines of projects, he said, would be assessed in the first instance by a five-person panel including himself and the director general of research councils, Sir John Cadogan. After the submission of fuller bids - in which the basic science in a project would be peer reviewed - the panel will present a provisional shortlist to the Foresight steering group, which will advise ministers on a final shortlist. Successful bidders will be notified in March next year. The call for a second round of projects will begin in June 1996.

Proposals did not have to be at the "nearmarket" stage, as this would imply that industry was already involved. "We are looking for groups of people who wouldn't nor-

\section{Australian researchers prepare for strike}

Sydney. Plans for an unprecedented halfday strike by scientists in a division of Australia's Commonwealth Scientific and Industrial Research Organisation (CSIRO) - believed to be the first strike against management in its 70-year history - point to continuing unrest in the country's main publicly funded research organization.

The strike is scheduled to occur this week, and involves scientists in the CSIRO's Division of Building Construction and Engineering in Melbourne. The stoppage has been called in response to a change in research priorities that will lead to the termination of various research programmes.

The division has 60 senior project officers, and of these about six or seven

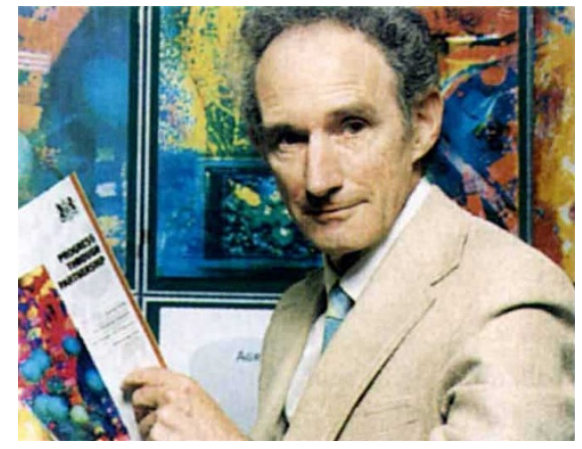

mally talk to each other, to stretch an idea to create a product," says May. "It's an incentive for researchers to look for industry, and for industry to look for researchers."

May adds that the government does not expect the exercise to result in "a product on the shelf" within three years. "But a fair fraction of them should have progressed from an idea to the point where you could begin ramping them up to a pilot project." He adds that there are no prescriptions for royalties and intellectual property rights. "It is up to the partners to hammer that out."

Signs are already emerging that Britain's research councils are shifting their funding. priorities to tie in with the conclusions of the Technology Foresight, launched in 1993 in the wake of the government's white paper on science. Last week, for example, the Engineering and Physical Sciences Research Council (EPSRC) launched Achievements in Chemistry, a booklet highlighting the - distinctly applied - projects funded by the EPSRC in chemistry. An accompanying EPSRC statement pointed out that the research council's $£ 33$ million chemistry programme "is helping to support a thriving base for wealth creation". Ehsan Masood
May: seeking 'imaginative proposals'. scientists are to be redeployed as a result of the changes. Alan Reid, chief of the Institute of Minerals, Energy and Construction - which includes the building division claims that the planned strike is "more of a protest rally". He says that both the staff and their labour union have been fully informed of the changes, which are being introduced as part of the division's efforts to respond to the needs of the market and Australian industry.

But Sandy Ross, a spokesman for the CSIRO section of the Public Sector Union, says that the staff are seeking clear written explanations setting out why proposals for the continuation of certain projects had been rejected.

Mark Lawson 